\title{
PENERAPAN MODEL 3LGM (THE THREE LAYER GRAPH-BASED META MODEL) PADA RANCANGAN ARSITEKTUR ENTERPRISE SISTEM INFORMASI AKADEMIK
}

\author{
Abadi Nugroho ${ }^{1}$ \\ ${ }^{1}$ Teknik Informatika, Sekolah Tinggi Teknologi Bontang \\ abadi@stitek.ac.id
}

\begin{abstract}
ABSTRAK
Perancangan sebuah sistem informasi akan lebih mudah dilakukan dengan adanya panduan cetak biru Arsitektur Enterprise. Dokumen tersebut akan memandu para pengembang Sistem Informasi dalam setiap pengembangannya. Dokumen cetak biru Arsitektur Enterprise yang sangat panjang dan terperinci membuat para pengembang memerlukan waktu yang cukup lama untuk mempelajarinya. Pada saat implementasi pelanggan pasti mempunyai keinginan proses pembuatan aplikasi segera bisa dilakukan. Dengan adanya kondisi tersebut akan membuat para pengembang cukup kesulitan sehingga memerlukan sebuah solusi untuk permasalahan tersebut. Pada penelitian kali ini akan mencoba memberikan solusi terkait dengan permasalahan tersebut. Solusi yang ditawarkan yaitu dengan membuat sebuah rancangan model yang lebih sederhana dengan menggunakan konsep 3LGM (The Three Layer Graph-Based Meta Model). Dari rancangan arsitektur enterprise yang Panjang dan rumit akan disederhanakan untuk membantu mempercepat pemahaman dari konsep sistem yang akan dibagun. Konsep 3LGM (The Three Layer GraphBased Meta Model) memformulasikan sebuah model Arsitektur Enterprise dengan tiga layer yaitu domain layer, logical layer dan physical layer. Pada penelitian ini menggunakan studi kasus Sistem Informasi Akademik. Hasil akhir dari penelitian ini yaitu menformulasikan cetak biru Arsitektur Enterprise dengan menggunakan konsep 3LGM (The Three Layer Graph-Based Meta Model).
\end{abstract}

Kata Kunci: 3LGM, Arsitektur Enterprise, Sistem Informasi Akademik

\section{APPLICATION OF THE THREE LAYER GRAPH-BASED META MODEL (THE THREE LAYER META MODEL) IN THE ARCHITECTURAL DESIGN OF ACADEMIC INFORMATION SYSTEMS ENTERPRISE}

\begin{abstract}
The design of an information system will be easier to do with the Enterprise Architecture blueprint guide. This document will guide Information System developers in each of their developments. The very long and detailed Enterprise Architecture blueprint document takes developers a long time to study it. At the time of implementation, the customer must have the desire that the application creation process can be carried out immediately. With these conditions will make it quite difficult for developers so that they need a solution for these problems. In this study, we will try to provide solutions related to these problems. The solution offered is to create a simpler model design using the 3LGM (The Three Layer Graph-Based Meta Model) concept. From the long and complex design of enterprise architecture, it will be simplified to help accelerate the understanding of the concept of the system to be built. The 3LGM (The Three Layer GraphBased Meta Model) concept formulates an Enterprise Architecture model with three layers, namely the domain layer, logical layer and physical layer. This research uses a case study of Academic Information Systems. The final result of this research is to formulate an Enterprise Architecture blueprint using the $3 L G M$ (The Three Layer Graph-Based Meta Model) concept.
\end{abstract}

Keyword: $3 L G M$, Enterprise Architecture, Academic Information Systems 


\section{PENDAHULUAN}

Saat ini sebagian besar organisasi perusahaan sudah menggunakan pendekatan Arsitektur Enterprise (EA) sebagai alat untuk meningkatkan kekuatan perusahaan dalam pengaturan Teknologi Informasi yang digunakannya [1]. Belum ada kesepakatan definisi terkait dengan Arsitektur Enterprise [2]. Beberapa peneliti terkait dengan Arsitektur Enterprise menjelaskan bahwa Arsitektur Enterprise merupakan sebuah visi yang terintegrasi dari sumber daya Teknologi Informasi perusahaan yang diwujudkan dalam elemenelemen (manusia, proses, aplikasi dan sebagainya) dan saling terhubung antara satu dengan yang lainnya [3]-[5].

Perusahaan yang sudah menggunakan Arsitektur Enterprise akan sangat terbantu pada pengembangan perusahaannya dengan terjadinya keselarasan antara Teknologi Informasi dan proses bisnis [6]-[8]. Dengan terjadinya keselarasan antara Teknologi Informasi dan proses bisnis tentu akan memberikan keuntungan tersendiri bagi perusahaan [9]. Keuntungan yang didapat antara lain menstandarkan pengelolaan Teknologi Informasi, lebih hemat dan fleksibel dalam penggunaan anggaran, [10], [11]. Dengan adanya Arsitektur Enterprise juga akan memudahkan dalam proses akuisisi sebuah perusahaan jika akan terjadi kedepannya [12].

Dari beberapa kelebihan yang ada ternyata ada beberapa tantangan yang bisa dihadapi oleh perusahaan dengan adanya Arsitektur Enterprise. Tantangannya yaitu keterbatasan sumber daya manusia yang terlibat dalam pengembang aplikasi serta keinginan pelanggan yang harus segera dilaksanakan dan sering kali sangat cepat perubahannya. Pada saat merancang arsitektur enterprise sudah pasti akan membutuhkan waktu yang lama kemudian nanti masih akan dibagun aplikasinya. Dengan pola seperti itu pengembang aplikasi akan sangat kesulitan dalam mengikuti kondisi yang ada. Untuk membantu pengembang aplikasi perlu dicarikan sebuah solusi untuk membantu mereka memahami rancangan arsitektur enterprise yang sudah ada. Salah satu solusi yang bisa dilakukan yaitu dengan membuat model arsitektur enterprise yang ada kedalam model 3LGM(The three layer graph-based meta model). Untuk memudahkan mempelajarinya maka peneliti akan membuat studi kasus pada Sistem Informasi Akademik.

Model yang akan dihasilkan yaitu model sistem informasi akademik dengan menggunakan konsep 3LGM(The three layer graph-based meta model) . Konsep tersebut terdiri dari 3 layer yaitu domain layer, logical layer, dan physical layer [13], [14]. Domain layer pada model 3LGM (The Three Layer Graph-Based Meta Model) menggambarkan fungsi enterprise secara menyeluruh dan proses bisnis yang ada. Pada domain Logical Layer menggambarkan aplikasi yang mendukung fungsi enterprise. Pada komponen aplikasi mempunyai fungsi sebagai pemroses (Processing), penyimpanan (Storage) dan mengirimkan data (transportation) yang mewakili jenis entitas. Physical Layer terdapat komponen fisik seperti perangkat server, komputer, router, switch dan sebagainya yang terhubung melalui jaringan wireless, kabel dan sebagainya.

\section{METODE PENELITIAN}

Tahapan awal yang dilakukan dalam pelaksanaan penelitian yaitu dengan melakukan studi literatur. Tahapan ini dilakukan untuk mengumpulkan dan mencari referensi terkait dengan tema penelitian yang dikerjakan. Kegiatan ini bertujuan untuk mendukung dan menguatkan terkait dengan rujukan penelitian yang akan dilakukan. Selanjutnya akan dilakukan pengamatan terkait dengan proses bisnis yang terkait dengan studi kasus yang diangkat di dalam penelitian yaitu sistem informasi akademik atau SIAKAD. Tahapan berikutnya yaitu mengidentitikasikan model arsitektur mulai dari arsitektur bisnis, arsitektur data, arsitektur aplikasi dan arsitektur teknologi. Penjelasan pada tahapan arsitektur enterprise adalah sebagai berikut:

\section{Arsitektur bisnis}

Pada tahapan ini peneliti mempelajari terkait dengan pola maupun alur bisnis yang terjadi saat ini. Semua aktor yang terlibat dalam layanan sistem informasi akademik akan dipelajari dan digambarkan. Mulai dari aktor yang keterlibatannya sangat sedikit hingga aktor yang paling dominan dalam keterlibatannya diaplikasi. Pada arsitektur bisnis semua kegiatan yang dilakukan oleh perusahan akan tergambar pada arsitektur ini.

\section{Arsitektur data}

Setelam mempelajari alur bisnis selanjutnya akan dilakukan pengumpulan data. Data yang dimaksud yaitu data yang akan digunakan dalam rancangan model yang akan dibuat. Pada saat penentuan data nantinya akan ditinjau dan dipertimbangkan terkait dengan sejauh mana data tersebut dinilai penting dalam aplikasi sehingga akan mendukung arsitektur bisnis yang dibuat. Penentuan arsitektur data akan berpengaruh kedalam pembuatan arsitektur aplikasi. Dengan seperti itu maka perlu identifikasi yang lengkap. 


\section{Arsitektur Aplikasi}

Tahapan selanjutnya yaitu membuat arsitektur aplikasi. Pada arsitektur aplikasi akan berisi beberapa fitur yang telah dirancang sebelumnya. Pada arsitektur ini bisa mengakomodasi dari arsitektur data yang telah dirancang. Pada arsitektur aplikasi terdapat beberapa modul aplikasi yang digunakan untuk mendukung proses bisnis yang ada. Kelengkapan dari arsitektur aplikasi akan berpengaruh terhadap arsitektur teknologi yang akan digunakan.

\section{Arsitektur Teknologi}

Tahapan akhir dari perancangan arsitektur yaitu perancangan arsitektur teknologi. Para perancangan arsitektur ini akan sangat mempertimbangkan pada teknologi yang ada saat ini yang disesuaikan dengan kondisi yang ada. Tujuan dari digunakannya teknologi informasi ini bisa memudahkan dan mendorong pemencfaatan teknologi informasi sehingga diharapkan bisa tercipta keselarasan antara teknologi dan proses bisnis.

Tahapan terakhir yaitu dengan melakukan menyusunan model dengan konsep 3LGM (The three layer graph-based meta model). Gambaran alur penelitian dapat dilihat pada gambar 1 .

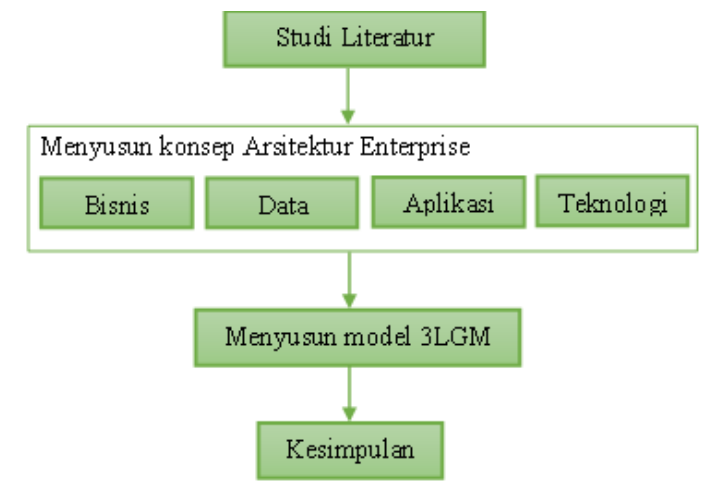

Gambar 1. Alur Penelitian

\section{HASIL DAN PEMBAHASAN}

Hasil akhir dari penelitian ini yaitu model Arsitektur Enterprise yang digambarkan dengan menggunakan konsep model 3LGM (The Three Layer Graph-Based Meta Model). Sebelum dilakukan penggambaran model perlu ada atau dibuat terlebih dahulu rancangan arsitektur enterprise mulai dari arsitektur bisnis, arsitektur data, arsitektur aplikasi dan arsitektur teknologi. Kemudian dari model dari Arsitektur Enterprise yang dibuat dilakukan Analisa dan disesuaikan dengan kebutuhan yang ada. Kelengkapan dari penggambaran arsitektur enterprise akan semakin memudahkan pengembang dan pengguna model dalam memahami sistem secara garis besar.
Pengembang dan pengguna tidak perlu membuka lembaran cetak biru yaang sangat rumit dan membutuhkan waktu yang cukup lama untuk dipahami. Pendefinisian dalam konsep arsitektur enterprise yaitu bisnis, data, aplikasi dan teknologi pada bepelitian ini adalah sebagai berikut :

\section{Arsitektur Bisnis}

Pada bagian ini akan membahas terkait dengan kegiatan bisnis yang terjadi. Pada tahapan ini juga akan membahas terkait dengan aktor yang terlibat didalam proses bisnis. Ringkasan arsitektur bisnis terdapat pada Tabel 1.

TABEL 1. RINGKASAN ARSITEKTUR BISNIS

\begin{tabular}{cll}
\hline No & Arsitektur Bisnis & Keterlibatan Aktor \\
\hline 1 & Proses pendaftaran & BAAK \\
& mahasiswa baru & BAUK \\
& & Mahasiswa \\
2 & Proses penentuan & BAAK \\
& pembimbing & Dosen \\
& akademik & Mahasiswa \\
3 & Proses pembuatan & BAAK \\
& Jadwal Kuliah & Prodi \\
4 & Proses pengelolaan & Dosen \\
& nilai Mahasiswa & Mahasiswa \\
& & BAAK \\
\hline
\end{tabular}

Pada proses pendaftaran mahasiswa baru ada beberapa aktor yang terlibat diantaranya BAUK, BAAK dan mahasiswa. Mahasiswa berperan sebagai aktor utama dalam aplikasi kemudian BAAK akan melakukan verifikasi dari proses yang dilakukan oleh mahasiswa. Jika terkait dengan masalah pembayaran maka aktor BAUK yang akan terlibat untuk melakukan verifikasi pembayaran. Selanjutnya pada proses penentuan pembimbing akademik, aktor yang terlibat yaitu BAAK, dosen dan mahasiswa. Mahasiswa akan melakukan proses bimbingan dengan dosen yang ditunjuk oleh BAAK sebagai dosen perwalian.

Proses yang ketiga yaitu proses pembuatan jadwal kuliah. Pada proses ini hanya ada dua aktor saja yang terlibat di dalam prosesnya. Jadwal akan dibuat oleh BAAK dengan melakukan koordinasi dengan program studi yang terkait. Proses terakhir yaitu proses pengelolaan nilai mahasiswa. Pada proses ini ada tiga aktor yang terlibat yaitu dosen, mahasiswa dan BAAK. Setelah melakukan perkuliahan maka dosen akan memberikan nilai kepada setiap mahasiswa yang diajarnya. Bagian BAAK akan melakukan pengawasan terhadap kegiatan dosen dalam menginputkan nilai kepada mahasiwa. Mahasiswa akan bisa melihat nilai jika semua nilai sudah selesai diinput dan dilakukan verifikasi oleh pihak BAAK. 


\section{Arsitektur data}

Arsitektur data digunakan sebagai komponen pendukung dari arsitektur bisnis yang ada. Pada arsitektur data akan dibahas terkait dengan data yang akan mengakomodasi dari proses bisnis. Dalam penentuan data yang digunakan apan dipertimbahan dari tingkat kepentingan data sebagai pendukung dalam arsitektur yang dirancang. Arsitektur data dapat dilihat pada gambar 2.
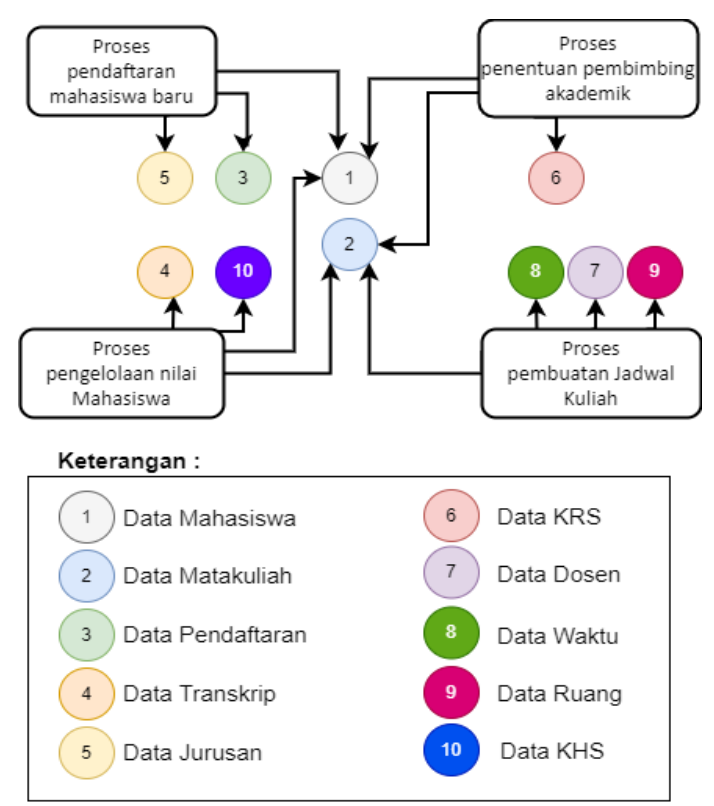

Gambar 2. Arsitektur data

a. Proses pendaftaran mahasiswa baru

Proses pendaftaran mahasiswa baru setidaknya ada tida data yang terlibat di dalam rancangan tersebut. Data yang terlibat yaitu data mahasiswa, data pendaftaran, dan data jurusan.

b. Proses penentuan pembimbing akademik

Proses penentuan pembimbing akademik pada rancangan yang telah dibuat terdapat tiga data yang terlibat. Data yang terlibat pada rancangan tersebut yaitu data mahasiswa, data mata kuliah dan data KRS.

c. Proses pengelolaan nilai

Pada proses pengelolaan nilai ada empat data yang terlibat. Data tersebut diantaranya data mahasiswa, data matakuliah, data transkrip dan data KHS.

d. Proses pembuatan jadwal kuliah

Proses pembuatan jadwal praktikum pada rancangan yang dibuat melibatkan ada empat data. Data tersebut diantaranya yaitu data matakuliah, data waktu, data dosen dan data ruang.

\section{Arsitektur Aplikasi}

Arsitektur aplikasi mempunyai fungsi untuk melakukan pendifinisian dari jenis-jenis aplikasi utama yang diperlukan untuk mengelola data dan mendukung kegiatan bisnis. Arsitektur ini dirancang berdasarkan dari arsitektur data dan arsitektur bisnis yang dijalankan. Arsitektur aplikasi dapat dilihat pada Tabel 2:

TABEL 2. RINGKASAN ARSITEKTUR APLIKASI

\begin{tabular}{cll}
\hline No & $\begin{array}{l}\text { Arsitektur } \\
\text { Aplikasi }\end{array}$ & Keterangan \\
\hline 1 & $\begin{array}{l}\text { Modul } \\
\text { pendaftaran } \\
\text { mahasiswa }\end{array}$ & $\begin{array}{l}\text { Modul ini berisikan } \\
\text { informasi untuk mengelola } \\
\text { terkait dengan pendaftaran } \\
\text { untuk mahasiswa baru. }\end{array}$ \\
2 & $\begin{array}{l}\text { Modul } \\
\text { pembimbing } \\
\text { akademik }\end{array}$ & $\begin{array}{l}\text { Modul ini digunakan untuk } \\
\text { mengelola terkait dengan } \\
\text { bimbingan akademik yang } \\
\text { telah dilakukan. }\end{array}$ \\
3 & $\begin{array}{l}\text { Modul } \\
\text { jadwal } \\
\text { kuliah }\end{array}$ & $\begin{array}{l}\text { Modul ini digunakan untuk } \\
\text { mengelola } \\
\text { perkuliahan yang dijalankan } \\
\text { di kampus. }\end{array}$ \\
& Modul nilai \\
mahasiswa & $\begin{array}{l}\text { Modul ini digunakan untuk } \\
\text { mengelola nilai mahasiswa. }\end{array}$ \\
\hline
\end{tabular}

\section{Arsitektur Teknologi}

Pada tahapan terakhir dalam pembuatan model arsitektur enterprise yaitu arsitektur teknologi. Arsitektur teknologi dirancangan untuk mendukung dari arsitektur sebelumnya yaitu bisnis, data dan aplikasi. Pada perancangan arsitektur teknologi perlu dipertimbangkan dengan kemajuan teknologi yang ada saat ini. Perancangan yang dilakukan harus hemat dan efisien sehingga perusahaan akan bisa mendapatkan hasil yang maksimal. Jika salah dalam penentuan teknologi yang digunakan akan terjadi pemborosan karena arsitektur yang terkait dengan hardware akan mengalami penyusutan. Jika tidak tepat bisa juga menghambat kinerja aplikasi karena infrastruktur tidak bisa mendukung aplikasi secara optimal. Arsitektur teknologi terdapat pada Gambar 3.

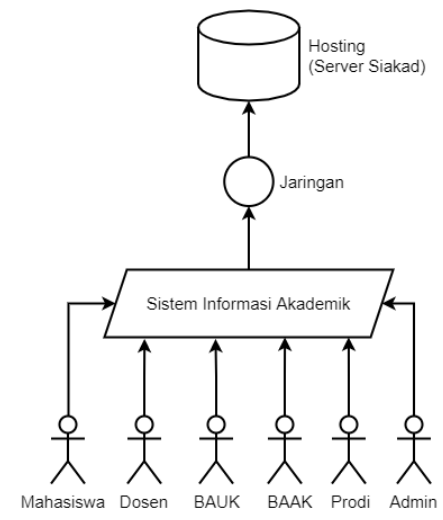

Gambar 3. Arsitektur Teknologi 
Dari beberapa rancangan dari setiap Arsitektur maka selanjutnya akan dimodelkan dalam bentuk 3LGM (The Three Layer GraphBased Meta Model). Model yang dihasilkan bisa dilihat pada Gambar 4.

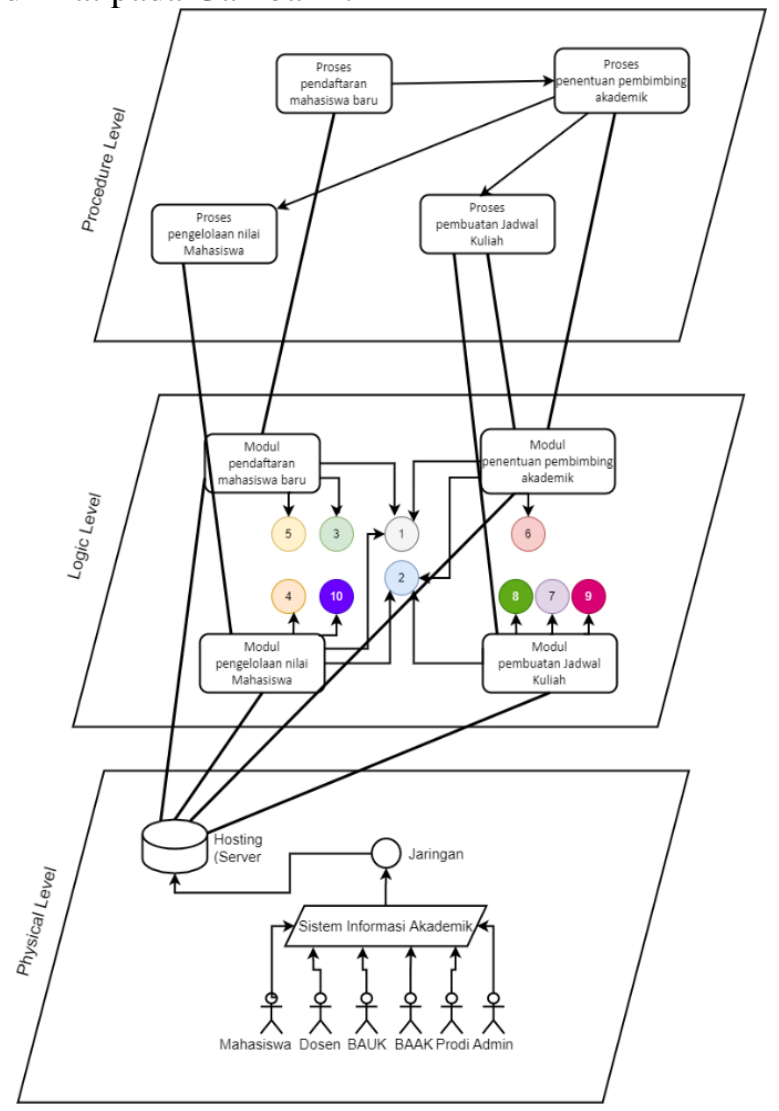

Gambar 4. Model 3LGM(The Three Layer Graph-Based Meta Model) Siakad

\section{KESIMPULAN}

Simpulan dari penelitian yang telah dilakukan yaitu dengan memodelkan arsitektur enterprise kedalan model 3LGM akan memudahkan bagi para pengembang aplikasi. Kemudahan ini didapatkan karena konsep dari model 3LGM(The Three Layer Graph-Based Meta Model) sangat sederhana dan mudah untuk dipahami. Bagianbagian dari arsitektur enterprise yang sangat panjang bisa langsung dilihat dari model layer yang dihasilkan. Pengembang aplikasi akan mudah melihat mulai dari proses bisnis yang ada kemudian ditranformasikan ke dalam modul yang akan dibuat dalam desain sistem aplikasi dan teknologi yang akan diunakan untuk mendukung aplikasi yang ada

\section{DAFTAR PUSTAKA}

[1] S. R. Mirsalari and M. Ranjbarfard, "A model for evaluation of enterprise architecture quality," Evaluation and Program Planning, vol. 83, p. 101853, 2020.

[2] E. Robertson, G. Peko, and D. Sundaram, "Enterprise Architecture Maturity: A Crucial Link in Business and IT Alignment.," in PACIS, 2018, p. 308.

[3] Y. Gong and M. Janssen, "The value of and myths about enterprise architecture," International Journal of Information Management, vol. 46, pp. 1-9, 2019.

[4] J. W. Ross, P. Weill, and D. Robertson, Enterprise architecture as strategy: Creating a foundation for business execution. Harvard business press, 2006.

[5] J. A. Carvalho and R. D. Sousa, "Enterprise architecture as enabler of organizational agility: A municipality case study," 2014.

[6] D. Gonçalves, L. Ferreira, and N. Campos, "Enterprise architecture for high flexible and agile company in automotive industry," Procedia Computer Science, vol. 181, pp. 1077-1082, 2021.

[7] M. Levy and Q. N. Bui, "How field-level institutions become a part of organizations: A study of enterprise architecture as a tool for institutional change," Information and Organization, vol. 29, no. 4, p. 100272, 2019, doi: https://doi.org/10.1016/j.infoandorg.2019.10027 2.

[8] P. Bhattacharya, "Aligning Enterprise Systems Capabilities with Business Strategy: An extension of the Strategic Alignment Model (SAM) using Enterprise Architecture," Procedia Computer Science, vol. 138, pp. 655-662, 2018, doi: https://doi.org/10.1016/j.procs.2018.10.087.

[9] G. Shanks, M. Gloet, I. Asadi Someh, K. Frampton, and T. Tamm, "Achieving benefits with enterprise architecture," The Journal of Strategic Information Systems, vol. 27, no. 2, pp. 139-156, 2018, doi: https://doi.org/10.1016/j.jsis.2018.03.001.

[10]W. F. Boh and D. Yellin, "Using Enterprise Architecture Standards in Managing Information Technology," Journal of Management Information Systems, vol. 23, no. 3, pp. 163-207, Dec. 2006, doi: 10.2753/MIS0742-1222230307.

[11]C. Schmidt and P. Buxmann, "Outcomes and success factors of enterprise IT architecture management: empirical insight from the international financial services industry," European Journal of Information Systems, vol. 20, no. 2, pp. 168-185, Mar. 2011, doi: 
10.1057/ejis.2010.68.

[12]G. Toppenberg, S. Henningsson, and G. Shanks, "How Cisco Systems used enterprise architecture capability to sustain acquisitionbased growth," MIS Quarterly Executive, vol. 14, no. 4, pp. 151-168, 2015.

[13]B. Brigl, T. Wendt, and A. Winter, "Modeling interdependencies between business and communication processes in hospitals," in The New Navigators: from Professionals to Patients, IOS Press, 2003, pp. 863-868.

[14] T. Wendt, A. Häber, B. Brigl, and A. Winter, "Modeling Hospital Information Systems (Part 2): using the 3LGM2 tool for modeling patient record management," Methods of Information in Medicine, vol. 43, no. 03, pp. 256-267, 2004. 